In the transformed coordinates, let us represent the point with complex coordinates $\left(x^{\prime}+i x^{\prime \prime}, y^{\prime}+i y^{\prime \prime}\right)$ by a vector from $\left(x^{\prime}, y^{\prime}\right)$ to $\left(x^{\prime}+x^{\prime \prime}, y^{\prime}+y^{\prime \prime}\right)$. If we change to another pair of conjugate axes $O X_{1}, O Y_{1}$ the coordinates are changed to $x_{1}^{\prime}+i x_{1}^{\prime \prime}$, $y_{1}^{\prime}+i y_{1}^{\prime \prime}$, but the vector is left unchanged since its end points are.

Consider, however, the intersections of $C$ with $L$. These are given by $x^{\prime}=\infty, x^{\prime \prime}=0, y^{\prime}=0, y^{\prime \prime}= \pm i x^{\prime}$. That is, the points $x^{\prime}, \pm y^{\prime \prime}$ are the intersections of $y= \pm x$ with $L$.

But the lines $y= \pm x$ change when we change the axes as above. Thus the vectors taken to represent the intersections of $C$ with $L$ also change.

If with Cauchy we represent $\left(x^{\prime}+i x^{\prime \prime}, y^{\prime}+i y^{\prime \prime}\right)$ by a vector joining the real points on the circular rays through it, we meet the same difficulty. For these real points are $\left(x^{\prime}+y^{\prime \prime}, y^{\prime}-x^{\prime \prime}\right)$ and $\left(x^{\prime}-y^{\prime \prime}, y^{\prime}+x^{\prime \prime}\right)$; that is, in the case under consideration, they are $(\infty, 0)$ and $(0,0)$ so that the direction changes as $O X$ does.

Von Staudt's representation is, however, unimpaired; since his imaginary intersection is the involution of all the point pairs cut out on $L$ by the involution of all the line pairs $y= \pm x$. The vector representation should then be regarded as a symbol, adapted to the particular coordinates used, for the more complete Von Staudt representation.

UNIVERSITY OF NHBRASKA, July 16, 1909 .

\title{
MAUROLYCUS, THE FIRST DISCOVERER OF THE PRINCIPLE OF MATHEMATICAL INDUCTION.
}

BY DR. G. VACCA.

Introductory Note. - Soon after the publication of my review of Voss's address (BuLLETIN, volume 15, page 405), wherein I considered at some length the history of mathematical induction, I received a note from Professor Moritz Cantor of Heidelberg, in which he called my attention to Dr. Vacca's research on this same historical topic. As Dr. Vacca's research was not accessible to me, I wrote to him for information and received, in reply, the following notes, which will doubtless be of general interest to American readers. - Florian CaJorI.

Many years ago I published in the Formulaire de Mathé- 
matique of Professor Peano an account of the first discovery of mathematical induction, as due to the Italian Maurolycus. But this paper seems to have had only a small diffusion. I think it useful, therefore, to give, with some more details, a short account of this important discovery.

\section{I.}

Franciscus Maurolycus was born in Messina in the year 1494, and died in the same city in the year 15\%5. His works on the Greek mathematical authors, Euclid, Archimedes, Apollonius, Theodosius, and many others, have been of the greatest importance for the transmission of Greek science to Europe. But the most original of his works is the treatise on arithmetic "Arithmeticorum libri duo" written in the year 1557 and printed in Venice in the year 1575 in the collection "D. Francisci Maurolyci Opuscula mathematica."

In the Prolegomena to this work he points out that neither in Euclid nor in any other Greek or Latin writer (among them he enumerates Iamblichus, Nicomachus, Boetius) is there, to his knowledge, a treatment of the polygonal and polyhedral numbers, and he reproaches Jordanus for having been content with a useless repetition of what was written by Euclid.

"Nos igitur [he says] conabimur ea, quae super hisce numerariis formis nobis occurrunt, exponere : multa interim faciliori via demonstrantes, et ab aliis authoribus aut neglecta, aut non animadversa supplentes."

This new and easy way is nothing else than the principle of mathematical induction. This principle is used at the beginning of the work only in the demonstration of very simple propositions, but in the course of the treatise is applied to the more complicated theorems in a systematic way.

For instance, he demonstrates at first that: "omnis quadratus cum impari sequente coniunctus, constituit quadratum sequentem (Prop. 13)." [In modern symbols : if $a$ is a number, then $\left.a^{2}+(2 a+1)=(a+1)^{2}\right]$.

Using this result, he now demonstrates that:

" Ex aggregatione imparium numerorum ab unitate per ordinem successive sumptorum construuntur quadrati numeri continuati ab unitate, ipsisque imparibus collaterales (Prop. 15)" [in modern symbols :

$$
\left.1+3+5+7+\cdots+(2 a+1)=(a+1)^{2}\right] .
$$


"Nam per $\mathrm{P} 13$, unitas imprimis cum impari sequente, facit quadratum sequentem, scilicet 4 . Et ipse 4 quadratus secundus, cum impari tertio, scilicet 5, facit quadratum tertium, scilicet 9 . Itemque 9 quadratus tertius, cum impari quarto, scilicet 7, facit quadratum quartum, scilicet 16 . Et sic deinceps in infinitum, semper $\mathrm{P} 13$ repetitam propositum demonstratur."

The form adopted by Maurolycus with the object of persuading the reader of the truth of his demonstrations is generally the following. He applies the reasoning to the first numbers, very often to the first five, and then he concludes with some one of these phrases :

"et eodem syllogismo pro quovis alio assignato loco, utemur ad roborationem propositi (pag. 30, Prop. 65)."

" et argumentatio a quinto loco ad alia quaevis loca transferet ur ad conclusionem propositi (pag. 31, Prop. 66).

"et a quinto loco transfertur syllogismus ad quemvis alium, ut propositio conclusit (pag. 33, Prop. 67)."

There are in this work many other points of interest for the history of mathematical knowledge, but I hope to be able to write something on it at another occasion.

\section{II.}

But now we have a question before us. Was Pascal unaware of the book of Maurolycus?

In his Traité du triangle arithmétique, printed perhaps in the year 1657, he never mentions Maurolycus, notwithstanding that, in my opinion, this treatise is only an application of the method discovered by Maurolycus. But Pascal, shortly after, being engaged in the polemic concerning the cycloid, in the well-known letter "Lettre de Dettonville à Carcavi" had to demonstrate a proposition concerning the triangular and pyramidal numbers. He says then :*

\section{"Cela est aisé Par Maurolic."}

It is strange to point out that not even the name of Maurolycus has been included in the Table analytique of the old edition of the works of Pascal, and more strange that the editors of the new edition of the "Oeuvres" of Pascal $\dagger$ in a very incomplete

* B. Pascal, Oeuvres complètes, tome troisième, Paris, Hachette, 1889, page 377 .

† Blaise Pascal, Oeuvres par Léon Brunschwigg et Pierre Boutroux. Paris, Hachette, 1908, in 3 vols. 
historical note before the reimpression of the Traite du triangle arithmétique (volume 3, pages 435-444) never mention the name of one of the greatest European mathematicians of the sixteenth century.

Genoa, Italy,

June, 1909.

\section{DARWIN'S SCIENTIFIC PAPERS.}

Scientific Papers. By Sir George Howard Darwin, K.C.B., F.R.S., Plumian Professor in the University of Cambridge. Vol. I, Oceanic Tides and Lunar Disturbance of Gravity, xiv + 463 pp.; Vol. II, Tidal Friction and Cosmogony, xvi + 516 pp. Cambridge University Press, 1907, 8. Royal 8vo.

IF one were in need of an example to illustrate the English use of the term "applied mathematics," it would hardly be possible to find a better one than that furnished by the scientific papers of Sir George Darwin. Many investigations ranging from the purest of pure mathematics to the observational portions of the phenomena of nature have at times been placed under this title in our journals and treatises, and after all our language is governed by general usage and not by arbitrary rules. But in the use of an imported term it would seem better, in spite of the customs of late years, to take the foreign value rather than the domestic as the basis of definition. This definition implies an actual or suggested relation between a problem set forth on arbitrary hypotheses and the observed phenomena of matter in space. The course which the argument follows - the laying down of hypothetical laws approximating as nearly as may be to those of nature, the translation into and development of those laws by means of symbols, and the final transference from the symbols back to the phenomena, is well known. The skill of the applied mathematician is chiefly shown in his management of the second of these stages so as to produce as much as possible in the third.

One cannot read any of Professor Darwin's papers without noting this attitude towards his work, and it is markedly shown in the excellent prefaces with which he introduces the papers contained in the two volumes under consideration. In them he gives a clear synopsis of each memoir, with observations on the results obtained. These observations are almost always on 